\title{
CREATIVE ECONOMY BASED ON SYARIAH AS AN EFFORT TO INCREASE COMMUNITIES WELFARE: Case Study at BAPPEDA, East Java Province, 2019
}

\author{
Syamsuri \& Muhammad Reno Fathur Rahman \\ Fakultas Ekonomi dan Manajemen Universitas Darussalam Gontor \\ Jl. Raya Siman Km. 6, Kabupaten Ponorogo, Jawa Timur, 63471 \\ e-mail: syamsuri@unida.gontor.ac.id,renofathur@gmail.com
}

\begin{abstract}
This study aims to analyze the government's creative economic strategy in improving the welfare of the community, especially in the BAPPEDA of East Java Province and also to find out the efforts of regional governments in developing a sharia-based creative economy. Descriptive qualitative research methods are used by the author as an approach in this study. Data collection techniques are by documentation, interviews and observation. The results of the study indicate that the government's creative economic strategies are established by building synergy with pentahelix elements, motivating innovation, realizing the "smart economy" program, and collaboration with BEKRAF. It also explained that the efforts of the regional government in developing a sharia-based creative economy are by producing halal products and involving syaria institutions into pentahelix elements and implementing the concept of mashlahah in creative economic activities.
\end{abstract}

\begin{abstract}
Abstrak: Ekonomi Kreatif Syariah Sebagai Upaya Peningkatan Ekonomi Umat. Penelitian ini bertujuan menganalisis strategi ekonomi kreatif pemerintah dalam meningkatkan kesejahteraan masyarakat, terutama di BAPPEDA Provinsi Jawa Timur, dan bagaimana upaya pemerintah daerah mengembangkan ekonomi kreatif berbasis syariah. Metode penelitian ini adalah kualitatif deskriptif dengan teknik pengumpulan data dokumentasi, wawancara, dan observasi. Hasil penelitian menunjukkan bahwa strategi ekonomi kreatif pemerintah dilakukan dengan bersinergi dengan elemen pentahelix, motivasi semangat dan inovasi, sadar program "smart economy", dan kerjasama dengan BEKRAF. Hasil penelitian juga menjelaskan bahwa upaya pemerintah daerah dalam mengembangkan ekonomi kreatif berbasis syariah adalah dengan menghasilkan produk-produk ekonomi kreatif yang halal dan syar'i, melibatkan institusi syariah ke dalam elemen pentahelix, dan menerapkan konsep mashlahah dalam kegiatan ekonomi kreatif.
\end{abstract}

Kata Kunci: Ekonomi kreatif, kesejahteraan, ekonomi kreatif syariah 


\section{Introduction}

The East Java Provincial Government seeks to focus on the development of this creative economy for industrial groups that have a dominance of value creation by utilizing the intellectuality of human resources. ${ }^{1}$ Creative economy is an economic activity that prioritizes creativity thinking to create something new and different, and has value and is commercial in nature. Creative economy has a close relationship with the creative industry, but the creative economy has a broader scope than the creative industry. ${ }^{2}$ Creative economy is seen as a driver of growth and economic development of a nation. This can be seen from the many creative economies that emerged in various cities in Indonesia and opened employment, increased people's income, improved technology, and other social roles. ${ }^{3}$ The creative economy that develops in each region varies according to the resources available in each region, and each sector has different advantages. ${ }^{4}$ With the development of the creative economy, people become better and motivated to use unlimited resources, namely ideas, talents, and creativity. ${ }^{5}$

Islam explains that human welfare contains the meaning of hasanah fi dunya (world) and hasanah fi al-âkhirah (hereafter), both of them must be balanced and may not be biased. ${ }^{6}$ Welfare in Islam is not only measured by material aspects, but also measured spiritually. ${ }^{7}$ This is evidenced by the existence of maqâshid al-syar'iyah in Islam, which guards human wealth. Allah SWT will not command anything, but in it benefits. ${ }^{8}$ Benefit in Islam is divided into three types; first, dharûriyyah (Primary Needs) that cannot be abandoned by humans, Secondly, the hâjjyyyah (Secondary Needs) which if done will provide humanity with ease and eliminate difficulties, Third, tahsiniyyah (Tertiary Needs) which if it left, is no problem, but if it done, is better. ${ }^{9}$ All of these needs explain that Islam maintains human benefit not

${ }^{1}$ Biro Administrasi Perekonomian Sekda Provinsi Jawa Timur, Roadmap Pengembangan Ekonomi Kreatif Jawa Timur 2014-2018 (Pemerintah Provinsi Jawa Timur, Surabaya, 2014), p. 5.

${ }^{2}$ Metasari Kartika Dan Hendarmin, "Pemetaan Ekonomi Kreatif Subsektor Kuliner di Kota Pontianak," in Jurnal Ekonomi Bisnis dan Kewirausahaan, Vol. 7 No. 1, 2018, p. 60.

${ }^{3}$ Badan Ekonomi Kreatif, (Accessed on 14 Maret 2019, at 11.00 PM, from site http:// indonesiakreatif.bekraf.go.id).

${ }^{4}$ Bahren, Herry Nur Hidayat, et al., "Industri Kreatif Berbasis Potensi Seni dan Sosial Budaya di Sumatera Barat," in Jurnal Ekspresi Seni, Vol. 16 No. 1, 2014, p. 154.

${ }^{5}$ Nasrudin Ali, "Peran Ekonomi Kreatif dalam Pemberdayaan Ekonomi Masyarakat di Desa Tulung Agung Kecamatan Gading Rejo Kabupaten Pringsewu" (Skripsi Sarjana: Universitas Islam Negeri Raden Intan Lampung, 2018), p. 87.

${ }^{6}$ Syamsuri, Ekonomi Pembangunan Islam Sebuah Prinsip Konsep dan Asas Falsafahnya (Ponorogo: UNIDA Gontor Press. 2018), p. 93.

${ }^{7}$ Ibid., p. 93.

${ }^{8}$ Ismardi Ilyas, "Stratafikasi Maqashid al-Syari'ah Terhadap Kemaslahatan dan Penerapannya," in Jurnal Hukum Islam, Vol. 14 No. 1, 2014, p. 14.

${ }^{9}$ Abû Hâmid al-Ghazâlî, Al-Mustashfâ min Ilmi al-Ushûl (Lebanon: Dâr al-Kutub al'Ilmiyyah, t.t), p. 274-27. 
only in terms of material, but all aspects of life. Mashlahah that is desired by Islam is not a problem for personal interest only, but is an essential wealth related to the public interest. ${ }^{10}$

Creative Economy is developing in Indonesia. Reporting from the official website of Jawa Pos, the development of the creative economy in East Java is currently growing at 6 percent. ${ }^{11}$ That was also felt to be a great potential to build East Java. Based on the consideration of the results of the mapping study of creative industries in East Java, the focus of developing the real potential creative industries includes the craft, fashion, design, culinary, music, and film, video and photography sectors. ${ }^{12}$ Some cities such as Aceh and Lombok are engaged in tourism, Bandung which is engaged in culinary advertising are the example of several cities that improve the economy through creative economy in Indonesia. ${ }^{13}$ The field of creative economy in each region also varies, some are engaged in crafts, culinary, tourism, advertising, etc. ${ }^{14}$ In its implementation, there are advantages and disadvantages of each. Slowly the economy of the Indonesian people increases with the existence of this economic movement, but the application of the Islamic economy in Indonesia is still very low. ${ }^{15}$

Creative economy has become one of the issues that has great potential to advance and improve the welfare of a nation, in this case the government has the authority and power to regulate and regulate all economic activities in a region. All kinds of government policies will have an impact on people's lives. The government's strategy in improving the creative economic sector must be right on target, so that people can become more prosperous. Judging from the existing data, the creative economy in East Java province has been shown to have a major impact on people's lives. Therefore this research will discuss how the strategy of the East Java Province in developing the creative economy sector, to improve the welfare of the community, and discuss the efforts of regional governments in developing a shariabased creative economy to improve people's welfare.

\section{Research Methodology}

Descriptive qualitative research methods are used by the author as an approach of this study. Qualitative method is a research method based on postpositivism philosophy,

${ }^{10}$ Ismardi Ilyas, Stratafikasi Maqâshid al-Syarî‘ah, p. 19.

${ }^{11}$ Sari Hardiyanto, Ekonomi Kreatif Jadi Bekal Bangun Jawa Timur (Accessed on 27 Oktober 2018, at 04.00 PM, from site https://www.jawapos.com).

${ }^{12}$ Biro Administrasi, Roadmap Pengembangan, p. 6.

${ }^{13}$ Dias Satria dan Ayu Prameswari, "Strategi Pengembangan Industri Kreatif Untuk Meningkatkan Daya Saing Pelaku Ekonomi Lokal," in Jurnal Aplikasi Manajemen, Vol. 9, No. 1, 2011, p. 302.

${ }^{14}$ Abbi Satya, Contoh Ekonomi Kreatif yang Berkembang di Berbagai Daerah Indonesia. (Accessed on 15 Maret 2019, at 00.30 AM, from site https://kodediskonruangguru.com).

${ }^{15}$ Aam Slamet Rusydiana, "Analisis Masalah Pengembangan Perbankan Syariah di Indonesia: Aplikasi Metode Analytic Network Process," in Esensi: Jurnal Bisnis dan Manajemen, Vol. 6 No. 2, 2016, p. 244. 
where researchers become key instruments in research, sampling data sources is done by purposive and snowball, data collection uses triangulation techniques, data analysis is inductive, and research results emphasize meaning rather than generalization. ${ }^{16}$ The location of the study was conducted at the Office of Badan Perencanaan Pembangunan Daerah (BAPPEDA) of East Java Province, Surabaya. BAPPEDA of East Java Province was chosen because this agency is a government agency that plays a role in regional development planning in various fields, and the economic field is one of the important fields in improving community welfare.

The technique of data collection is done by triangulation. Triangulation is defined as a technique that combines several different data collection techniques from the same source. This technique was chosen because researcher wants to get the valid and credible data, and researcher can understand all the problems in depth. This study uses inductive analysis techniques in processing the data obtained. Inductive analysis is testing the problem in the data that has been collected, the inductive thinking process begins by drawing conclusions from the collected data, which is then taken in general conclusions. ${ }^{17}$ Data obtained through interviews in this study were also analyzed using descriptive analysis, namely by describing data obtained from the results of interviews with informants as a whole, and describing the characteristics of the data obtained from the sample. ${ }^{18}$

\section{Literature Review}

\section{Creative Economy}

The creative economy is actually a manifestation of efforts to seek sustainable economic development through creativity. The main message offered by the creative economy is the unlimited use of resources, namely talent, ideas, and creativity. ${ }^{19}$ Creative Economy is a term used by economists to define a home industry that sells creative ideas to generate income. ${ }^{20}$ Creative Economy is also referred to as a new talent that changes people's life through creative ideas or thoughts, resulting in economic value-added products that can make life more prosperous. ${ }^{21}$ Creative economy is defined as talents (creative-innovative ideas) with economic values that are able to change the quality of life of human beings to be

16 Sugiyono, Metode Penelitian Bisnis (Bandung: Penerbit Alfabeta, 2009), p. 14.

${ }^{17}$ Angga Prasteya, Metode Analisis Data Kualitatif Induktif (Accessed on 12 November 2018, at $10.00 \mathrm{AM}$, from site http://kajiansekolap.com).

${ }^{18}$ V. Wiratna Sujarweni, Metodologi Penelitian Bisnis dan Ekonomi (Yogyakarta: Pustaka Baru Press, 2015), p. 122.

${ }^{19}$ Departemen Perdagangan Republik, Pengembangan Ekonomi Kreatif Indonesia 2025 (Jakarta: Kementerian Perdagangan RI., 2008), p. 76.

${ }^{20}$ Herie Saksono, "Ekonomi Kreatif: Talenta Baru Pemicu Daya Saing Daerah," in Jurnal Bina Praja, Vol. 4 No. 2, 2012, p. 93.

${ }^{21}$ Ibid., p. 93. 
more prosperous. The creative economy relies more on individual creativity through ideas, talents, and creativity. So as to be able to create jobs and welfare for the wider community. ${ }^{22}$

Based on the Presidential Regulation (Perpres) No. 72 In 2015, the Creative industry is grouped into 16 sectors, each of which has the title of each description ${ }^{23}$, namely:

1. Architecture: Architecture in general can be described as a science in designing the built environment and includes designing and building the entire built environment. ${ }^{24}$

2. Interior Design: Interior Design is an activity that solves the problems of function and interior quality, provides services related to interior space to improve quality of life, and fulfills aspects of public health, safety and comfort. ${ }^{25}$

3. Visual Communication Design: Visual communication media is a form of communication using graphic design in which there are elements of typography, photography and illustrations. ${ }^{26}$

4. Product Design: Product design is understood as a professional service that creates and develops concepts and specifications that optimize the function, value and appearance of a product. ${ }^{27}$

5. Film, Animation, Video: Video is a system of live images or sequential moving images. There are two types of videos, analog video and digital video. ${ }^{28}$

6. Photography: An understanding of photography is about capturing light and making it a beautiful picture. Someone who studies cinematography will learn how to make videos and films. ${ }^{29}$

7. Craft: Craft art is an activity that changes raw material with skills that can be learned as a predetermined product. ${ }^{30}$

${ }^{22}$ Ibid., p. 96.

${ }^{23}$ Peraturan Presiden No. 72 Tahun 2015.

${ }^{24}$ Bondan Prihastomo, "Pergeseran Paradigma dan Persepsi Karya Arsitektur Bagi Arsitek di Era Informasi," in Jurnal Arsitektur dan Perencanaan, Vol.1 No. 1, 2017, p. 3.

${ }^{25}$ Tim Studi dan Kementerian Pariwisata Ekonomi Kreatif, Ekonomi Kreatif: Rencana Pengembangan Desain Nasional 2015-2019 (Jakarta: Republik Solusi, 2015), p. 136.

${ }^{26}$ Giandari Maulani, Siti Nur Janah, Yuri Alam Mahbubi, "Desain Media Komunikasi Visual Berbentuk Tabloid," in Jurnal Ilmiah SISFOTENIKA, Vol. 7 No. 1, 2017, p. 62.

${ }^{27}$ Tim Studi dan Kementerian Pariwisata Ekonomi Kreatif, Ekonomi Kreatif: Rencana Pengembangan, p. 136.

${ }^{28}$ Diana Ayu Hapsari dan Yunan H Urbani, "Pembuatan Film Dokumenter Wanita Tangguh Dengan Kamera DSLR Berbasis Multimedia," in Indonesian Journal on Networking and Security, Vol. 3 No 1, 2014, p. 22.

${ }^{29}$ Tunjung Riyadi, "Sinematografi Dengan Kamera DSLR," in Jurnal Humaniora, Vol. 5 No. 2, 2014, p. 920.

${ }^{30}$ Sefmiwati, "Pengembangan Pembelajaran Seni Kriya Menggunakan Teknik Pemodelan Berbasis Pendekatan Saintifik," in Jurnal Penelitian Guru Indonesia, Vol. 1 No. 1, 2016, p. 38. 
8. Culinary: The culinary word comes from commodities related to cooking and eating activities. ${ }^{31}$

9. Music: Outward forms of art can be observed and lived. There are visual forms of art, namely art results that can be experienced by the senses. ${ }^{32}$

10. Fashion: Fashion is a kind of dress code that sets lifestyle standards according to age, gender, social class and so on. ${ }^{33}$

11. Application and Game Developer: Application Software can also be defined as a term in the world of computers that represents specially formatted data. ${ }^{34}$

12. Publishing: Issuance originates from the word "publish" which begins with an understanding of "the issuing of a written or printed work" or information written or work that is printed. ${ }^{35}$

13. Advertising: Advertising is a form of information on products and services from producers to consumers and the delivery of messages from sponsors through a media. ${ }^{36}$

14. Television and Radio: Television and radio are basically activities to disseminate information and ideas to the public carried out simultaneously. ${ }^{37}$

15. Performing Arts: Artistic activities that involve performers who interpret a material to the audiences, both through speech, music, movement, dance and even acrobatics. ${ }^{38}$

16. Fine Art: Fine art is a branch of art that prioritizes the manifestation of an artist's idea or concept into a form that stimulates the sense of sight, which in its development has surpassed the limitations of the visual itself. ${ }^{39}$

The concept of creative economy is to use human resources in the form of ideas, talents, thoughts, and intellectuals to develop and utilize existing natural resources. Human reason

${ }^{31}$ Auzan Tawadlu Akbar and Edriana Pangestuti, "Peran Kuliner Dalam Meningkatkan Citra Destinasi Pariwisata," in Jurnal Administrasi Bisnis, Vol. 50 No. 1, 2017, p. 155.

${ }^{32}$ Galuh Prestisa and Bagus Susetyo, "Bentuk Pertunjukan dan Nilai Estetis Kesenian Tradisional Terbang," in Jurnal Seni Musik, Vol. 2 No. 1, 2013, p. 4.

${ }^{33}$ Ade Nur Istiani, "Konstruksi Makna Hijab Fashion Bagi Moslem Fashion Blogger," in Jurnal Kajian Komunikasi, Vol. 3 No. 1, 2015, p. 52.

${ }^{34}$ Asti Herliana and Prima Muhamad Rasyid, "Sistem Informasi Monitoring Pengembangan Software Pada Tahap Development Berbasis Web," in Jurnal Informatika, Vol. 3 No.1, 2016, p. 43.

${ }^{35}$ Tim Studi dan Kementerian Pariwisata Ekonomi Kreatif, Ekonomi Kreatif: Rencana Pengembangan Penerbitan Nasional 2015-2019 (Jakarta: Republik Solusi, 2015), p. 4.

${ }^{36}$ Ambar Lukitaningsih, "Iklan Yang Efektif Sebagai Strategi Komunikasi Pemasaran," in Jurnal Ekonomi dan Kewirausahaan, Vol. 13 No. 2, 2013, p. 117.

${ }^{37}$ Tim Studi dan Kementerian Pariwisata Ekonomi Kreatif, Ekonomi Kreatif: Rencana Pengembangan Televisi dan Radio Nasional 2015-2019 (Jakarta: Republik Solusi, 2015), p. 2.

${ }_{38}$ Tim Studi dan Kementerian Pariwisata Ekonomi Kreatif, Ekonomi Kreatif: Rencana Pengembangan Seni Pertunjukan Nasional 2015-2019 (Jakarta: Republik Solusi, 2015), p. 6.

39 Tim Studi dan Kementerian Pariwisata Ekonomi Kreatif, Ekonomi Kreatif: Rencana Pengembangan Seni Rupa Nasional 2015-2019 (Jakarta: Republik Solusi, 2015), p. 3. 
is the main actor in every creative economic activity. The basic foundation of this creative economic concept is science and technology. In the concept of Islamic economics, human ideas and thoughts must still be within the limits of the Shari'a that have been set by Allah SWT. There are four philosophical bases of Islamic economics, namely tauhid, rubûbiyyah, khaliffah, and tadzkiyyah. This cannot be separated because in Islam, the rules of religion are the basic principles before determining anything in life. For example, if someone has an idea or thought to make a culinary business, food that is sold must be healthy and halal food and drink, because if he sells food or drinks that are haram, then he has violated religious rules, and in Islam it is strictly prohibited.

\section{Welfare in Islam}

Understanding of welfare according to the Indonesian dictionary comes from the word prosperous which has a safe, secure, prosperous, and safe meaning, regardless of all kinds of disturbances, difficulties, etc. ${ }^{40}$ Community welfare will be achieved if all human activities are based on Islamic Economics or Islamic Economics. Although not all people believe in resolving economic, social, political, legal, cultural, and various natural problems, this paradigm provides a perfect understanding of the universe. ${ }^{41}$ Welfare in Islam according to Abû Hâmid al-Ghazâli is the achievement of maslahah. Maslahah itself is the goal of syara' maintenance (maqâshid al-syar'iyah). Humans cannot feel happiness and inner peace, but after achieving the true welfare of all humanity in the world through fulfilling spiritual and material needs. To reach the goal of syara in order to realize the benefit, he described the source of welfare, namely the maintenance of religion, soul, mind, lineage and wealth. ${ }^{42}$ Economic development in Islam aims to achieve falâh in the world and the hereafter. The purpose of this concept is to improve the standard of living of the people and it must be accompanied by the intention and purpose of getting the blessing of Allah SWT. ${ }^{43}$

In the perspective of Islam, welfare is when a person can play his role on this earth in accordance with his nature as a servant of Allah SWT, as well as being a serving caliph with all constructive qualities. Therefore welfare is the one that carries the meaning of sa'âdah fi dâraini (Glory of the world and the hereafter). ${ }^{44}$ Indicators of hasanah in the world

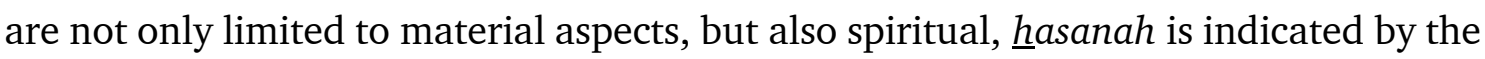

${ }^{40}$ Kamus Besar Bahasa Indonesia (KBBI), edisi ke-5, 2016.

${ }^{41}$ Almizan, "Distribusi Pendapatan: Kesejahteraan Menurut Konsep Ekonomi," in Jurnal Kajian Ekonomi Islam, Vol. 1, No.1, 2016, p. 65.

${ }^{42}$ Ibid., p. 77.

${ }^{43}$ Syamsuri and Okta Yuripta Syafitri, "Maqâshid al-Syarî́ah Approach on the Empowerment of Human Resources in Mulyodadi Village Bantul Yogyakarta," in Jurnal MIQOT, Vol. 42, No.2, 2018, p. 386.

${ }^{44}$ Syamsuri, Ekonomi Pembangunan Islam Sebuah Prinsip Konsep dan Asas Falsafahnya (Ponorogo: UNIDA Gontor Press. 2018), p. 93. 
praiseworthy qualities taught by the Prophet Muhammad, such as the nature of shididq, amanah, tablîgh, and fâthanah. ${ }^{45}$ This concept agrees with the economic concept of al-Ghazâlî which means wealth is an achievement towards the success of an eternal life through the concept of faith, hereafter, and treatise. ${ }^{46}$ These elements will support and strengthen the mashlahah of society to be separated from maisr (speculation), gharâr (uncertainty), idkhâr (hoarding), and ribâ (interest). And prioritizing brotherhood, cooperation, and profit sharing, thus to create harmony in mutual respect without economic monopoly and market freedom without the role of government. ${ }^{47}$ The aim of economic development is to increase human welfare, manifested in the welfare function that was seen from objective economic development and contained additional goals of attainment in the afterlife. ${ }^{48}$

The concept of welfare in Islam is a very strong concept and covers all aspects of human life, namely the concept of maslahah. The concept of maslahah itself includes protection against faith (al-dîn), soul (al-nafs), reason (al-‘aql), descent (al-nasl), and wealth (al-mâl). Welfare is part of rahmatan li al-'âlamîn taught by Islam. Allah SWT. has promised welfare for all humanity, but that does not mean that welfare will be given away, God has set conditions and obligations for servants who want to get it. Welfare will be given by Allah SWT. if humans carry out what they are told and stay away from His prohibitions.

\section{Sharia Creative Economy}

Creative economy is a human effort in building the economy of the community to be better, using ideas, thoughts, talents, and creativity as its main tools. In Islamic perspective, creative economy relies heavily on human reason in all its sub-sectors, which is a fundamental thing that distinguishes between humans and other creatures. The concept of creative economy is to use human resources in the form of ideas, talents, thoughts, and intellectuals to develop and utilize existing natural resources. Human reason is the main actor in every creative economic activity. In the concept of Islamic economics, human ideas and thoughts must still be within the limits of the Shari'a that have been set by Allah SWT. There are four philosophical bases of Islamic economics, namely tauhîid, rubûbiyyah, khalîfah, and tadzkiyyah. This is what will become the main reference in carrying out economic activities in human life, such as not to violate things that have been banned by religion.

The author also explained that welfare in Islam is when the fulfillment of human material and spiritual needs are balanced, thus all aspects of human life are fair and prosperous. Welfare in Islam is a very strong concept and covers all aspects of human life, namely the

${ }^{45}$ Ibid., p. 93.

${ }^{46}$ Ibid., p. 93.

${ }^{47}$ Ibid., p. 95.

${ }^{48}$ Abul Hasan Muhammad Sadeq, "Economic Development in Islam," in Journal of King Abdulaziz University, Vol. 5, Jeddah-Saudi Arabia, 1993), p. 153. 
concept of mashlahah. Mashlahah is part of rahmatan li al-âlamn taught by Islam. Welfare will be given by Allah SWT. if humans carry out His commands and stay away from His prohibitions. In this study the author would like to discuss the government's strategy in carrying out creative economic programs in East Java which have a role in improving people's welfare. And making Islamic welfare indicators as the main reference, namely fulfilling material and spiritual needs that are balanced, and looking at maintaining aspects of religion, soul, mind, wealth, and descent.

\section{Result and Discussion}

\section{Government Strategy in Creative Economy}

The role of the government in terms of interference with the process of economic development for each country has different levels. In some countries there are governments that play an important role in the process of their economic development, on the contrary there are also those that only have little influence. ${ }^{49}$ High economic growth is one of the development trilogy that must be fulfilled as the foundation of development. Without a steady economic growth, growth in other fields will not be achieved well. ${ }^{50}$ When we talk about growth, of course we understand that what is meant is an increase in physical production, or in general terms called Gross Domestic Product (GDP). ${ }^{51}$ Theoretically, the total GDP is used to meet household consumption needs, investment needs, government needs for goods and services, foreign export needs, etc. ${ }^{52}$

A participatory and innovative society can spur the pace of development of a region's creative economy, with various innovations, people will be motivated to improve their standard of living. In this case BAPPEDA always drives the spirit and innovation of the community implicitly, by facilitating, accelerating, and stimulating various Regional Organizations (OPD) such as the trade service, cooperative services, and so on to plan and implement programs that trigger people's passion to develop ideas, their creativity, talents, and innovation in creative economic activities. thus the community becomes more prosperous with the existence of a productive economic movement. BAPPEDA also invites pentahelix elements to further innovate and move together in developing a creative economy. Some steps that have been taken by the government are conducting public education programs, discussion forums, seminars, and training on the creative economy..$^{53}$

49 Irawan dan Suparmoko, Ekonomika Pembangunan (Fakultas Ekonomika dan Bisnis Universitas Gadjah Mada, Edisi ke-enam, BPFE-Yogyakarta, 2014), p. 403.

${ }^{50}$ Ibid., p. 433.

${ }^{51}$ Ibid., p. 433-434.

${ }^{52}$ Ibid., p. 434.

${ }^{53}$ Interview with the Head of Tourism, Cooperatives, Small and Medium Enterprises 
From the explanation regarding creative economic activities in East Java Province, it can be concluded that the government, especially the Regional Development Planning Agency (BAPPEDA) of East Java Province has the aim of improving the welfare of the community through a creative economy with the following strategies:

a) Building Synergy with Multi Stakeholders or Elements of Pentahelix Creative Economy in East Java Province. In economic studies there are four factors of production, namely natural resources, human resources, capital, and orientation or management. ${ }^{54}$ The synergy that the government wants to achieve is with Pentahelix elements. Through the support of measurable and available up to date data, pentahelix or multi stakeholder elements consisting of academics, business, community, government, and media. The government builds synergy with various parties in fulfilling the above production factors, thus the growth of the creative economy can help improve people's welfare. ${ }^{55}$ Academics have a role in mapping, registering, and researching various creative economic activities in the community, and publishing the results of their research in various media. Business people are people or groups that have or run creative economies in various sub-sectors, they are the main actors in the creative economy. Communities play a role in gathering people who have the same interests, talents, and talents, who then can encourage each other to produce creative economic products. These products are then disseminated through mass media in the form of writing, images, reviews, videos, and so on. The government is only a regulator, accelerator and mediator between various parties related to creative economic activities. ${ }^{56}$

b) Synergizing and Harmonizing Efforts to Increase Creative Economy in East Java. According the increase in the creative economy contributes to the economy growth of East Java Province by an average of 9.15 percent. The government is trying to continue to synergize and harmonize various efforts in improving the creative economy in East Java by registering and recording assets that have the potential to generate regional economic growth and development. ${ }^{57}$ The data is then formulated into programs and plans for creative economic development. The government supports policies to protect creative economic products from plagiarism, through product certification, operational

Sub Division, Nurareni Widiastuti, BAPPEDA of East Java Province Office, Friday, $5^{\text {th }}$ of April 2019, at 01,00 PM.

${ }^{54}$ Ririn Noviyanti, "Peran Ekonomi Kreatif Terhadap Pengembangan Jiwa Entrepreneurship di Lingkungan Pesantren: Studi Kasus di Pondok Modern Darussalam Gontor Putri 1," in Jurnal Penelitian Ilmiah Intaj, Vol. 1 No.1, 2017, p. 83.

${ }^{55}$ Interview with the Head of Tourism, Cooperatives, Small and Medium Enterprises Sub Division, Nurareni Widiastuti, BAPPEDA of East Java Province Office, Friday, $5^{\text {th }}$ of April 2019, at 01,00 PM.

${ }^{56}$ Ibid., Jum'at, 5 April 2019, at 01.30 PM.

${ }^{57}$ Rusydi, Noviana, "Pengaruh Penerapan Ekonomi Kreatif Terhadap Kreativitas Remaja di Kota Lhokseumawe," in Jurnal Visioner \& Strategis, Vol. 5 No. 1, 2016, p. 53-54. 
standardization, and registration of Intellectual Intelligence Rights. ${ }^{58}$ This is in accordance with the Islamic perspective, which states that the government has the duty to make people aware by increasing their welfare by maintaining their soul, mind, religion, property, and offspring in carrying out economic activities. ${ }^{59}$ When all elements are maintained, the government will be easier to carry out efforts in improving the creative economy in the community, because people already understand why they are engaged in the creative economy, and they also understand how to make the creative economy useful and influence life they, especially the revitalization of culture or local wisdom in each region. In addition, people will be able to escape from maisr (speculation), gharâr (uncertainty), idkhâr (hoarding), and ribâ (usury). ${ }^{60}$

c) Powering the Spirit and Innovation of the Community of East Java Province Implicitly. The innovation and enthusiasm of the people still must be within reasonable limits and within the corridors of Islamic sharia. In Islamic teachings, the philosophical basis of development is explained. First, Tauhîd, which laid the foundation of the relationship between God and humans and humans with each other, thus there was no tyranny in the economy between humans. Secondly, rubûbiyyah, which states the basis of God's law to regulate the model of development that based on Islam. Third, khaliffah, which explains the status and role of humans as representatives of God on earth, thus people keep all their creations from nature and living things, use enough and maintain as well as possible. Fourth, tadzkiyyah, who explained that the main mission of the messenger of God is to purify humans in relation to God, humans, the environment, society and the state, thus the balance of life is maintained properly. ${ }^{61}$

d) Realizing a "Smart Economy" Program that is Digital-Based for All Creative Economy Activities. East Java Smart Province Governance has the purpose of mapping regional per-district/city and digital-based sub sectors, thus it can help communities improve their welfare. In this program there are three main programs, namely, smart governance, smart industry, and smart economy. One sector discussed in the smart economy is the creative economy sector. The economy is described as a big house that can create a digital system that has many functions, such as the functions of marketing, production and financing, which aims to make all economic activities digitally accessible. Digital-based access will make it easier to access creative economic products and record all transactions transparently. The expansion of connections between producers and consumers will also be prioritized, therefore the market can expand on a domestic and international scale. ${ }^{62}$

\footnotetext{
${ }^{58}$ Badan Perencanaan Pembangunan Daerah, Slide Seminar Perkembangan Ekonomi Kreatif di Jawa Timur, Peluang Dan Tantangan (Blitar, Jawa Timur).

${ }^{59}$ Syamsuri, Ekonomi Pembangunan Islam Sebuah Prinsip Konsep dan Asas Falsafahnya, p. 77.

${ }^{60}$ Ibid., p. 95.

${ }^{61}$ Fadlan, "Konsep Pembangunan Ekonomi Berbasis Islam: Sebuah Upaya Pembangunan Ekonomi Indonesia yang Adil, Makmur dan Sejahtera," in Jurnal Al-Ahkam, Vol. 5 No. 2, 2010, p. 264-265.

${ }^{62}$ Interview with the Head of Tourism, Cooperatives, Small and Medium Enterprises Sub 
e) Regional Government Collaborates with Creative Economy Agency (BEKRAF). The development of creative and digital economics has challenges, including the quality of human resources, the ability to capture quality workforce, regional disparities, international competition, less innovation-friendly public institutions, less competitive digital infrastructure, access to funding, and presence artificial intelligence. To deal with these challenges, BEKRAF cannot stand alone, BEKRAF expects cooperation and support from ministries and institutions of central and regional governments to realize the creative economy as the backbone of the Indonesian economy and also as part of the national development priority agenda. ${ }^{63}$ East Java is one of the regions that has plans to cooperate with BEKRAF by holding training, development and funding of creative economic programs, even though it is still in the process of collecting files to sign a Memorandum of Understanding with the central government. ${ }^{64}$

\section{Government Efforts in Developing Sharia Creative Economy}

In Indonesia, the Creative Economy contributed $7.38 \%$ to the total national economy. In the publication of BEKRAF (2016), the Gross Domestic Product of the Creative Economy GDP created in 2015 amounted to 852 trillion rupiah, from the previous year which ranged from 784 trillion rupiah, where in that year the Creative Economy GDP grew by $4.38 \%$. This means that the contribution of the creative economy is increasingly gaining a place to become the center of attention of the government. ${ }^{65} \mathrm{BEKRAF}$ also shows that the magnitude of the creative economy Regional Domestic Product (GRDP) at the current price, continues to experience a substantial increase as does the East Java Province GRDP. East Java has enormous potential to develop a creative economy, given the diversity of potential products, culture, and ideas created by people in East Java. If seen from the number of MSMEs scattered in East Java alone there are around 6 million more MSMEs in which of course there is creativity created.

Commodity is a real object that is relatively easy to trade, can be physically handed over, can be stored for a certain period of time and can be exchanged with other products of the same type. The criteria for superior products are commodities that meet the requirements of local resource sufficiency, commodity linkages, competitive positions and competitive potential. ${ }^{66}$

Division, Nurareni Widiastuti, BAPPEDA of East Java Province Office, Friday, $5^{\text {th }}$ of April 2019, at $01,00 \mathrm{PM}$.

${ }^{63}$ Mimi Zulaikha, "Dukungan Kementerian/Lembaga Dibutuhkan untuk Mewujudkan Rindekraf," (Accessed on 15 April 2019, at 06.30 PM, from site http://www.bekraf.go.id).

${ }^{64}$ Interview with the Head of Tourism, Cooperatives, Small and Medium Enterprises Sub Division, Nurareni Widiastuti, BAPPEDA of East Java Province Office, Friday, $5^{\text {th }}$ of April 2019, at 01,00 PM.

${ }^{65}$ Badan Ekonomi Kreatif (BEKRAF) 2016.

${ }^{66}$ Badan Perencanaan Pembangunan Daerah Provinsi Jawa Timur, Draf Laporan Akhir Pemetaan Potensi Ekonomi Kreatif Unggulan Jawa Timur (2018), p. 49. 
Each creative economy sub-sector has a role in creating added value and contributing to the formation of GRDP. In the case of East Java Province, it turns out that there are three creative economic sub-sectors that have a major contribution in the formation of East Java's creative economy GDP, namely the culinary sub-sector, the craft sub-sector, the fashion sub-sector. Each sub-sector has its own advantages, therefore it becomes the superior product of East Java Province. ${ }^{67}$

Islamic economic thinking was born from the fact that Islam is a system that was revealed by Allah SWT to all humans to organize all aspects of life in all space and time. ${ }^{68}$ In sharia economic affairs, the local government always supports and encourages the development of Islamic economics in East Java, because the sharia economic movement has a significant impact on the lives of East Javanese people whose majority are Muslim. According to BPS data in 2016, the population of East Java Province which is Muslim is $40,720,467$ people from a total population of 43,050,221 people.$^{69}$ However, for now there is still no specific agency or sector that handles sharia economics in the form of institutions. For now, Islamic economy is still considered as an alternative economic movement for the welfare of society. The government cannot make Islamic economics as the main basis in the regional economy, because not all people are Muslim, and not all people want to accept it. ${ }^{70}$

Although in East Java the sharia economy is growing rapidly, Islamic banking is increasing, and many Islamic boarding schools are established, the government still cannot impose all must be sharia-based. In the regional economy there are still many conventional banks that become government partners in various fields. However, it does not mean that the government has no efforts in developing the Islamic economy in East Java, planning that can be done by the government such as optimization of non-departmental Islamic institutions, utilizing the most of Islamic banking for funding, encouraging Islamic-based private economies such as Sharia Cooperatives and Amil Zakat Institutions, educating the public regarding Islamic economics by collaborating with relevant government institutions, developing Sharia Business Units in Regional Enterprises (BUMD), etc.

From the above explanation about the creative economy sub-sector along with its influence on the East Java Province GRDP and the development of the Islamic economic movement in East Java, it can be concluded that in order to realize a sharia-based creative economy in East Java Province, the following economic models are needed:

${ }^{67}$ Badan Perencanaan Pembangunan Daerah Provinsi Jawa Timur, Laporan Penyusunan PDRB Ekraf Provinsi Jawa Timur Menurut Lapangan Usaha 2010-2016.

68 Abdul Mujib, "Realitas Sistem Perbankan Syariah dan Ekonomi Islam," in Jurnal Masharif al-Syariah: Jurnal Ekonomi dan Perbankan Syariah, Vol. 2 No. 1, 2017, p. 16.

${ }^{69}$ Badan Pusat Statistik, Jumlah Penduduk Menurut Kabupaten/Kota dan Agama yang Dianut di Provinsi Jawa Timur, 2016.

${ }^{70}$ Interview with the Head of Tourism, Cooperatives, Small and Medium Enterprises Sub Division, Nurareni Widiastuti, BAPPEDA of East Java Province Office, Friday, 5th of April 2019, at $01.00 \mathrm{PM}$. 
Figure 1. Sharia-based Creative Economy Model

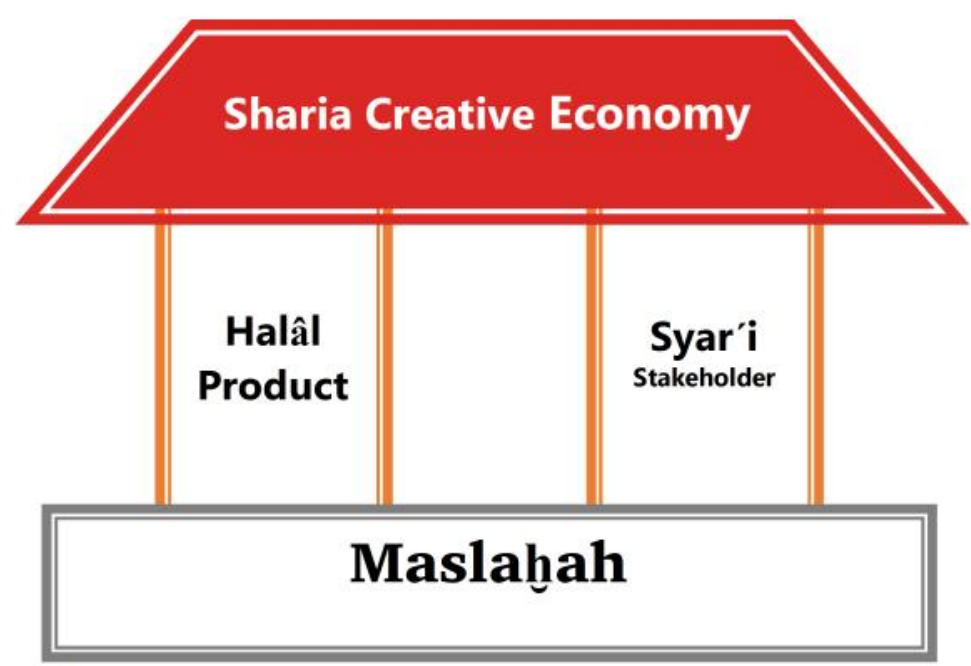

Source: Authors' Research Results

a) Producing Creative Economy Products that are Halal and Syar'i in Every Sub Sector. The word "Halâl" is a word that comes from Arabic which means it is permitted or in accordance with the law. Halal is anything that is permitted by the Shari'ah to be consumed or used. Whereas haram is something that by Allah is prohibited from being carried out with a strict prohibition in which the person who violates it is threatened by torture by Allah in the Hereafter. The concept of halal today has become a trend in the development of Islamic economics in Indonesia, starting from the emergence of halal products (food and beverages), halâl cosmetics, halal fashion, halal tourism, to halal lifestyle. The Tourism Ministry's Sharia Data Development Study final report in 2016 shows that the Islamic economy is an important part of the current global economy. There are seven Islamic economic sectors that have increased significantly, namely culinary, Islamic finance, insurance, fashion, cosmetics, pharmacy, entertainment, and tourism industries. Where the entire sector carries the concept of halal in each of its products. ${ }^{71}$

b) Involving Islamic Institutions Into Pentahelix Elements or Multi-Stakeholders. Paradigms and concepts of public policy innovation have become discourses and practices in government bureaucracies. In this context, public policy can be seen as a continuous and interrelated process carried out by the government together with stakeholders in regulating, managing existing resources for mutual interests. Creative economic actors interact to solve problems comprehensively and make decisions in the interest of various stakeholders involved in developing creative economic policies. The importance of stakeholder commitment and synergy in utilizing the momentum for the advancement of creative economic growth. By encouraging the existence of regulations regarding the development of the

${ }^{71}$ Hendri Hermawan Adinugraha, Mila Sartika, and Ana Kadarningsih, "Desa Wisata Halal: Konsep dan Implementasinya di Indonesia," in Jurnal Human Falah, Vol. 5 No. 5, 2018, p. 29-31. 
creative economy as a legal protection for stakeholders with synergy between various ministries and creative economic agencies as the leading sector. ${ }^{72}$

c) Implementing The Concept Of "Maslahah" In Creative Economic Activities. The concept of welfare in Islam is called mashlahah. Mashlahah is a concept that is very strong and covers all aspects of human life, both individually and collectively, and is very relevant to the achievement of social welfare and society, and in accordance with the objectives of sharia itself. The concept of well-being itself includes protection against faith (al-dîn), soul (al-nafs), reason (al-'aql), descent (al-nasl), and wealth (al-mâl)..$^{73}$ Thus it can be concluded that in carrying out sharia creative economic activities, the five concepts must always be maintained. Religion must be maintained by not leaving a human obligation to God in matters of worship. The soul is guarded by not producing or distributing food and beverages that are not halal. Intellect is guarded by not producing things that make the mind broken, such as uneducated videos or songs. Creative economic actors must also pay attention to the impact of creative economic products on subsequent generations, therefore the sustainable development can be achieved in social life.

\section{Conclusion}

Creative economy is a human effort in building the economy of the community to be better, using ideas, thoughts, talents, and creativity as its main tools. Human resources are the main element in this effort, because it is from humans that all of these thoughts emerge, which are then implemented into economic activities that trigger the community to grow and develop. Welfare in Islam is when the fulfillment of human material and spiritual needs are balanced, thus all aspects of human life are fair and prosperous. A person is considered prosperous when his life is free from ignorance of world knowledge and the hereafter, poverty of wealth and heart, fear of other than God, or excessive worry, thus his life is safe and peaceful, both physically and mentally. Badan Perencanaan Pembangunan Daerah (BAPPEDA) of East Java Province has the goal of improving the welfare of the community through the creative economy strategies as follows (1) Building synergy with multi stakeholders or elements of pentahelix creative economy in east java province. (2) Synergizing and harmonizing efforts to increase creative economy in east java. (3) Powering the spirit and innovation of the community of east java province implicitly. (4) Realizing a "smart economy" program that is digital-based for all creative economy activities. (5). Regional Government Collaborates with Creative Economy Agency (BEKRAF).

${ }^{72}$ Ahmad Sururi, "Inovasi Model Pengembangan Kebijakan Ekonomi Kreatif Provinsi Banten," in Jurnal Scientium, Vol. 6 No.1, 2017, p. 10.

${ }^{73}$ Martini Dwi Pusparini, "Konsep Kesejahteraan dalam Ekonomi Islam," in Islamic Economics Journal, Vol. 1 No. 1, 2015, p. 46. 
Badan Perencanaan Pembangunan Daerah (BAPPEDA) of East Java Province has the efforts to develop creative economy based on syariah through these efforts. (1) Producing creative economy products that are halâl and syar'i in every sub sector. (2) Involving Islamic institutions into pentahelix elements or multi-stakeholders. (3) Implementing the concept of "mashlahah" in creative economic activities.

\section{References}

Aam Slamet, Rusydiana. "Analisis Masalah Pengembangan Perbankan Syariah di Indonesia: Aplikasi Metode Analytic Network Process," in Esensi: Jurnal Bisnis dan Manajemen, Vol. 6, No. 22016.

Al-Ghazâlî, Abû Hâmid.Al-Mustashfâ min Tlmi al-Ushûl. Lebanon: Dâr al-Kutub al-'Ilmiyyah, n.y.

Almizan. "Distribusi Pendapatan: Kesejahteraan Menurut Konsep Ekonomi," in Jurnal Kajian Ekonomi Islam, Vol. 1, No. 12016.

Ambar, Lukitaningsih. "Iklan Yang Efektif Sebagai Strategi Komunikasi Pemasaran," in Jurnal Ekonomi dan Kewirausahaan, Vol. 13 No. 22013.

Angga, Prasteya. "Metode Analisis Data Kualitatif Induktif," in http://kajiansekolah.com, Accessed on 12 November 2018.

Asti, Herliana dan Prima Muhamad Rasyid. "Sistem Informasi Monitoring Pengembangan Software pada Tahap Development Berbasis Web," in Jurnal Informatika, Vol. 3 No.1 2016.

Badan Perencanaan Pembangunan Daerah Provinsi Jawa Timur. Draf Laporan Akhir Pemetaan Potensi Ekonomi Kreatif Unggulan Jawa Timur. 2018.

Badan Perencanaan Pembangunan Daerah Provinsi Jawa Timur. Laporan Penyusunan PDRB Ekraf Provinsi Jawa Timur Menurut Lapangan Usaha 2010-2016.

Badan Perencanaan Pembangunan Daerah. Slide Seminar Perkembangan Ekonomi Kreatif di Jawa Timur, Peluang dan Tantangan. Blitar: Jawa Timur.

Badan Pusat Statistik. Jumlah Penduduk Menurut Kabupaten/Kota dan Agama yang Dianut di Provinsi Jawa Timur, 2016.

Bahren, Herry Nur Hidayat, et al. "Industri Kreatif Berbasis Potensi Seni dan Sosial Budaya di Sumatera Barat," in Jurnal Ekspresi Seni, Vol. 16 No. 1, Juni 2014.

Biro Administrasi Perekonomian Sekda Provinsi Jawa Timur. Roadmap Pengembangan Ekonomi Kreatif Jawa Timur 2014-2018. Pemerintah Provinsi Jawa Timur, Surabaya, 2014.

Bondan Prihastomo. "Pergeseran Paradigma dan Persepsi Karya Arsitektur Bagi Arsitek di Era Informasi," in Jurnal Arsitektur dan Perencanaan, Vol. 1 No. 1, 2017.

Departemen Perdagangan Republik. Pengembangan Ekonomi KreatifIndonesia 2025. Jakarta: Kementerian Perdagangan RI., 2008.

Diana, Ayu Hapsari dan Yunan H. Urbani. "Pembuatan Film Dokumenter Wanita Tangguh 
Dengan Kamera DSLR Berbasis Multimedia," in Indonesian Journal on Networking and Security, Vol. 3 No 1, 2014.

Fadlan. "Konsep Pembangunan Ekonomi Berbasis Islam: Sebuah Upaya Pembangunan Ekonomi Indonesia yang Adil, Makmur, dan Sejahtera," in Jurnal al-Ahkam, Vol. 5 No. 22010.

Galuh, Prestisa dan Bagus Susetyo. "Bentuk Pertunjukan dan Nilai Estetis Kesenian Tradisional, Terbang," dalam Jurnal Seni Musik, Vol. 2 No. 1, 2013.

Giandari Maulani, Siti Nur Janah, Yuri Alam Mahbubi. "Desain Media Komunikasi Visual Berbentuk Tabloid," in Jurnal Ilmiah SISFOTENIKA, Vol. 7 No. 1, 2017.

Hendri, Hermawan Adinugraha, Mila Sartika, dan Ana Kadarningsih. "Desa Wisata Halal: Konsep dan Implementasinya di Indonesia," in Jurnal Human Falah, Vol. 5 No. 5, 2018.

Interview with the Head of Tourism, Cooperatives, Small and Medium Enterprises Sub Division, Nurareni Widiastuti, BAPPEDA of East Java Province Office, Friday, 5 th of April 2019.

Irawan dan Suparmoko. Ekonomika Pembangunan. Fakultas Ekonomika dan Bisnis Universitas Gadjah Mada, BPFE-Yogyakarta, 2014.

Ismardi, Ilyas. "Stratafikasi Maqashid al-Syari'ah Terhadap Kemaslahatan dan Penerapannya," in Jurnal Hukum Islam, Vol. 14 No. 1, 2014.

Kamus Besar Bahasa Indonesia (KBBI), edisi ke-5, 2016.

Martini, Dwi Pusparini. "Konsep Kesejahteraan dalam Ekonomi Islam," in Islamic Economics Journal, Vol. 1 No. 1, 2015.

Metasari, Kartika, dan Hendarmin. "Pemetaan Ekonomi Kreatif Subsektor Kuliner di Kota Pontianak," in Jurnal Ekonomi Bisnis dan Kewirausahaan, Vol. 7 No. 1, 2018.

Mimi, Zulaikha. Dukungan Kementerian/Lembaga Dibutuhkan untuk Mewujudkan RINDEKRAF. Accessed on 15 April 2019, http://www.bekraf.go.id.

Mujib, Abdul. "Realitas Sistem Perbankan Syariah dan Ekonomi Islam," in Jurnal Masharif al-Syariah: Jurnal Ekonomi dan Perbankan Syariah, Vol. 2 No. 1, 2017.

Nasrudin, Ali. "Peran Ekonomi Kreatif Dalam Pemberdayaan Ekonomi Masyarakat di Desa Tulung Agung Kecamatan Gading Rejo Kabupaten Pringsewu." Skripsi Sarjana, Universitas Islam Negeri Raden Intan Lampung, 2018.

Nur Istiani, Ade. "Konstruksi Makna Hijab Fashion Bagi Moslem Fashion Blogger," in Jurnal Kajian Komunikasi, Vol. 3 No. 1, 2015.

Ririn Noviyanti. "Peran Ekonomi Kreatif Terhadap Pengembangan Jiwa Entrepreneurship di Lingkungan Pesantren: Studi Kasus di Pondok Modern Darussalam Gontor Putri 1," in Jurnal Penelitian Ilmiah Intaj, Vol. 1 No.1, 2017.

Rusydi, Noviana. "Pengaruh Penerapan Ekonomi Kreatif Terhadap Kreativitas Remaja di Kota Lhokseumawe," in Jurnal Visioner \& Strategis, Vol. 5 No. 1, 2016.

Sadeq, Abul Hasan Muhammad, "Economic Development in Islam," in Journal of King Abdulaziz University, Vol. 5, Jeddah-Saudi Arabia, 1993. 
Saksono, Herie. "Ekonomi Kreatif: Talenta Baru Pemicu Daya Saing Daerah," in Jurnal Bina Praja, Vol. 4 No. 2, 2012.

Sari, Hardiyanto. Ekonomi Kreatif Jadi Bekal Bangun Jawa Timur. Accessed on 27 Oktober 2018, https://www.jawapos.com.

Satria, Dias dan Ayu Prameswari. "Strategi Pengembangan Industri Kreatif Untuk Meningkatkan Daya Saing Pelaku Ekonomi Lokal,” in Jurnal Aplikasi Manajemen, Vol. 9 No. 1, 2011.

Satya, Abbi. "Contoh Ekonomi Kreatif yang Berkembang di Berbagai Daerah Indonesia," Accessed on 15 Maret 2019, https ://kodediskonruangguru.com.

Sefmiwati. "Pengembangan Pembelajaran Seni Kriya Menggunakan Teknik Pemodelan Berbasis Pendekatan Saintifik," in Jurnal Penelitian Guru Indonesia, Vol. 1 No. 1, 2016.

Sugiyono. Metode Penelitian Bisnis. Bandung: Penerbit Alfabeta, 2009.

Sururi, Ahmad. "Inovasi Model Pengembangan Kebijakan Ekonomi Kreatif Provinsi Banten," in Jurnal Scientium, Vol. 6 No.1, 2017.

Syahnan, Mhd. "The Image of the Prophet and the Systematization of Ushul al-Fiqh: A Study of al-Shafi'i's Risalah", in MIQOT: Jurnal Ilmu-ilmu Keislaman, No. 103, 1998, pp. 44-50.

Syahnan, Mhd. Modernization of Islamic Law of Contract: A Study of 'Abd al-Razzaq alSanhuri's Masadir al-Haqq fi al-Fiqh al-Islami: Dirasah Muqaranah bi al-Fiqh alGharbi. Jakarta: Badan Litbang \& Diklat Departemen Agama RI, 2009.

Syamsuri, and Okta Yuripta Syafitri. "Maqâshid al-Syarî‘ah Approach on the Empowerment of Human Resources in Mulyodadi Village Bantul Yogyakarta," in MIQOT: Jurnal Ilmu-ilmu Keislaman, Vol. 42, No. 2, 2018.

Syamsuri. Ekonomi Pembangunan Islam Sebuah Prinsip Konsep dan Asas Falsafahnya. Ponorogo: UNIDA Gontor Press. 2018.

Tawadlu, Akbar Auzan, and Edriana Pangestuti. "Peran Kuliner Dalam Meningkatkan Citra Destinasi Pariwisata," in Jurnal Administrasi Bisnis, Vol. 50 No. 1, 2017.

Tim Studi dan Kementerian Pariwisata Ekonomi Kreatif, Ekonomi Kreatif: Rencana Pengembangan Desain Nasional 2015-2019. Jakarta: Republik Solusi, 2015.

Tim Studi dan Kementerian Pariwisata Ekonomi Kreatif. Ekonomi Kreatif: Rencana Pengembangan Penerbitan Nasional 2015-2019. Jakarta: Republik Solusi, 2015.

Tim Studi dan Kementerian Pariwisata Ekonomi Kreatif. Ekonomi Kreatif: Rencana Pengembangan Televisi dan Radio Nasional 2015-2019. Jakarta: Republik Solusi, 2015.

Tim Studi dan Kementerian Pariwisata Ekonomi Kreatif. Ekonomi Kreatif: Rencana Pengembangan Seni Pertunjukan Nasional 2015-2019. Jakarta: Republik Solusi, 2015.

Tim Studi dan Kementerian Pariwisata Ekonomi Kreatif. Ekonomi Kreatif: Rencana Pengembangan Seni Rupa Nasional 2015-2019. Jakarta: Republik Solusi, 2015.

Tunjung, Riyadi. "Sinematografi Dengan Kamera DSLR," in Jurnal Humaniora, Vol. 5 No. 2, 2014.

V. Wiratna, Sujarweni. Metodologi Penelitian Bisnis dan Ekonomi. Yogyakarta: Pustaka Baru Press. 2015. 